\title{
Selfcare Group Efforts To Increase The Confidence Of Lepers In Jeneponto, South Sulawesi
}

\author{
Syahridha ${ }^{1}$, Sapriadi.S ${ }^{2}$ \\ ${ }^{1}$ Department of Tropical Medicine, Faculty of Medicine,Airlangga University, East Java \\ ${ }^{I}$ Departemen of Infectious Diseases, Publich Health Office in Jeneponto Distric, South Sulawesi \\ ${ }^{2}$ Department of Nursing, STIK FAMIKA Makassar,South Sulawesi \\ *e-mail:syahridhasarea@gmail.com
}

\begin{abstract}
Leprosy, one of negledted tropical diseases, is a contagious disease that is so feared by all of people. It is still become one of the problems that faced by the world society because it can lead to a very complex problem. People who are suffering from leprosy may have disabilities that are settled if it does not get healing and handling well. As impact, lepers who had been leprosy diseases get some difficulties for instant, the anxiety to approach themselves into society, lost their social status progressively, isolated from family, friends, and society. therefore, the effort to avoid distabilty toward lepers is a self caring. Selfcare can prevent disability and encourage patient self-awareness to heals. It can be developed become a selfcare group that help lepers to support each other. Because there is a quote "senasib sepenanggungan" or camaraderie. The method that used in this research is survey study which collects data through a visit to the Baji Minasa Selfcare Group in Jeneponto regency. The results of this research stated that the self-care group gave an important role in enhancing lepers' confidence through their interaction and communication between each members, several activities and motivation that they gave . as conclusions, Self Care Group very helpful to increasing lepers' confidence. Suggestion: This activity can be developed throughout the health centers in Jeneponto. Also expected cross-sectoral cooperation in the development of Self Care Group.
\end{abstract}

Key word: Selfcare group, Lepers, confidence

\section{INTRODUCTION}

Leprosy, one of negledted tropical diseases, is a contagious disease that is so feared by all of people. It is still become one of the problems that faced by the world society because it can lead to a very complex problem. The problem is not only in terms of medical treatment but extends to social, economic, cultural, and national defense (Ministry of Health, 2006). Lepers may have disabilities that are settled if it does not get healing and handling well. Disability in patients with leprosy is still stigmatization in society, so it is difficult lepers are accepted in society even though the disease has been declared cured. Disability arising in lepers is a striking defect in the manifestation of leprosy. it begins to show mild symptoms of disability in a small area with anesthesia in hand then become serious condition such as shortening of the fingers and thumb on both hands, wrists and a decrease in bilateral, ulceration and deformity remain on the both feet, making them incapable to walk (Soomro, 2008).

Beside that, lepers who get defect in the eyes should receive serious attention because it is the most disturbing of disability for patients compared with disabilities in the hands and feet. As impact, lepers who had been leprosy deseas get some difficulties for instance, the anxiety to approach themselves into society, lost their social status progressively, isolated from family, friends, and society. lepers feel inferiority complex, depression and aloof and often ostracized by 
their families because of their disabilities. A fact that most people with leprosy came from from lower middle class make the matters worse. (Subramanian, 2010). Generally, this stigma gives a negative impact on leprosy patients. It can make lepers become social psycho disorder. Most leprosy patients have a simultaneous psychiatric disorder. In addition, social environment involving not only themselves, but also their role of the labor, their role in the family and in other social roles (relationships with friends, neighbors, colleagues, social activities group and family members. patients have the possibility to have a functioning social disruption as a result of leprosy, consequent disability, social stigma and occupational impairment. The addition of psychiatric morbidity in the group can also deteriorate effect on social adjustment (verma, 2010). Therefore, to avoid disability in patients with leprosy, need to do self-care so that defects can be prevented and disability does not continue for those who already have disabilities. It can be developed become a selfcare group that help lepers to support each other. Because there is a quote "senasib sepenanggungan" or camaraderie.

Based on the report by the World Health Organization (WHO), received from 138 countries from all WHO regions, the prevalence of leprosy at the end of 2015 was 176176 cases $(0.2$ cases per 100000 people). The number of new cases reported globally in 2015 was 211973 (2.9 new cases per 100000 people). In 2014, 213899 new cases were reported, and in 2013, 215656 new cases. In 2015, Indonesia reported 17202 new cases and 1,687 of them, found he was already disabled level 2 (defects appear) (Ministry of Health, 2016). While in the province of South Sulawesi recorded 1220 cases with 131 cases of disability level 2. In Jeneponto number of patients amount 72 patients in 2015 and increased in 2014, namely 67 patients and 14 cases of which are disability level I and II. Community health center in Bontoramba district, recorded there are 208 people who had suffered from leprosy deseas from 2005 to 2015 and there are 31 disabled level I and 23 disabled level II, and there are 5 new lepers in 2016. According to some informations, patients who have had leprosy still has limitations interact in society. So, they need to treatmented for increasing their confidence.

Based on this background, the author interest to write a scientific paper entitled "Selfcare Group Efforts to Increase The Confidence of Lepers" With the problem statement is how selfcare group can increase the confidence of lepers.

\section{METHODS}

The method used in this research is survey method with visit the Baji Minasa self-care group in Jeneponto regency. Therefore, get interviewing and documentation related to activities in Baji Minasa. selfcare group. This study held november 2016.

\section{RESULT}

Baji Minasa Self-care Group (SCG) in Community health center Bontoramba was formed since 23 september 2011. This program is a cooperation between wasor (deputy supervisor of Leprosy) in the comunity health center with wasor in regency and Nederland Leprosy Relief.

Each month, the Fasilitator lead the patients to do their selfcaring, mutual brainstorming and motivating each other. Currently the group has a membership of 34 participants and mutually motivate each other. In addition, there is a Leprosy Independent association, which also facilitated the needs of members of SCG both health-related problems as well as social and economic.

\section{The formation and development of Self Care Group}

The steps of the formation and development of Self Care Group performed:

a. Following the training about self-caring of lepers, in this case the activities facilitated by NLR and South Sulawesi Provincial Health department, wasor was given provision to form 
a self-care group and given an understanding of how to self-caring leprosy patient and other matters related to SCG

b. Motivated by wasor district, in this case wasor always give suppor that SCG can be in the form of at community health Center Bontoramba which is basically one of the barns of leprosy at the district in Jeneponto regency.

c. Advocacy by wasor District. Wasor advocate with the staff of health departement about thr esrablishment of the SCG in Jeneponto Regency.

d. Negotiations with the chief of the clinic center. Negotiate to the chief of the Community health Center center about the formation of self-care group, with the aim that clinic center can help and gives spot to the lepers to gathering in self-care group at the health center.

e. Selecting members of the Group. The Steps to be used in selecting which search for leprosy patients who suffered wounds on the feet and hands to become a member of the SCG, further to include new patients as members of the SCG.

f. preparing for the meeting. The meeting was held at the clinic center in the room P2M Leprosy, but the day before the officer visited the house to remind members attend the meeting.

g. Participate in Routine activities of SCG every month. Routine activities are carried out each month is a soak the foot / hand on the bucket, then scrub using pumice stone on the skin fter that dabing using cooking oil.

h. Develop the SCG's activities in micro-credit activitie. Currently the group has begun to develop self-care at the stage of granting savings and loans to members of self-care as well as their work in the form of woven handicrafts and manufacture ashtray

Restoration of confidence and problem solving

Stigma is a great fear against leprosy.With the stigma that developed in the community, then the patients will feel embarrassed by the disease they suffered, they feel embarrassed to socialize with relatives and their neighbors, so they prefer to spend time in the garden which is a place away from the crowds. The realitatif activities to overcome the stigma on leprosy patients in the treatment group self-Baji Minasa is measuring stigma in patients using Emic Stigma Scale, to determine whether the patient exposed to stigma or not implemented at the beginning and end of the year, granting motivated by PerMaTa (Perhimpunan Mandiri Kusta) which is an organization of leprosy patients and people affected by leprosy in which they have a good self confidence and has undertaken various activities especially in order to remove the stigma and discrimination of leprosy, and doing recreational activities, with the aim of bringing the patient to mingle with the public at large as well as to boost her confidence. And to explore the ability of the patient, in this case developed what they can do to improve the quality of life.

By exploring their ability with weaving, farming, and other handicrafts. Therefore, The selfcare group has become one of the efforts to increase the confidence of leprosy patients, with various activities in it and their sense of camaraderie among SCG members.

\section{CONCLUSIONS}

Leprosy is a contagious disease that is greatly feared by the public. The disease is still one of the problems faced by the world community because it can lead to a very complex problem. The problem is not only in terms of medical treatment but extends to social, economic, cultural. With the self-care group will increase the confidence of lepers. Self Care Group very helpful to increasing lepers' confidence. Suggestion: This activity can be developed throughout the health centers in Jeneponto. Also expected cross-sectoral cooperation in the development of Self Care Group. 


\section{REFERENCES}

Bryceson ADM, Pfaltzgraff RE.(1990). Introduction, The eye on leprosy, complication due to nerve damage.In: Leprosy, 3rd ed. London: Churchill Livingstone, Edinburgh.

Calcraff, J.H. (2012). Disability information resource. The effecth of the stigma of leprosy on the income generation of leprosy affected people in the terai area of south east Nepal.

Departemen Kesehatan RI.(2012). Buku Pedoman Nasional Pemberantasan Penyakit Kusta Cetakan XVIII.Jakarta

Ministry of Health. (2016). Health profil of Jeneponto Regency in 2015.

Nirwan Bahwan. (2007). Directorate General of Health Services Central Leprosy Division. NLEPguidelines on reduction of stigma and discrimination against persons affected by leprosy.

Soomro RF., Pathan,G.M.,Abbasi Parves, Bhatti,S.N., Hussain Javeed., Yoshihisahahiguchi. (2008). Journal of Pakistan Association of Dermatologists. Deformity and disability index in patients of leprosy in Larkana region.(18): p 29-32.

Subramaniam.P., Wong, M.L. (2010) Socio-cultural issues in Leprosy control and management.

Soedarto. (2009). Penyakit Menular di Indonesia. Sagung Seto. Jakarta

Verma, D.K.,Katoch, V.M., Katoch Kiran., Gupta, S.C., Jain Poornima., Tomar . S., ...Yaduvanshi. A.K. (2010) Indian Journal of Comunity Health. A Study of Sosial Stigma by the Neigbours among Leprosy patient of agraa ang kampur districth of U.P.21 (2), 8-12.

WHO. (2016).Leprosy. acces by http://who.int/mediacentre/factsheets/fs101/en/ 